\begin{tabular}{|c|c|c|}
\hline (1) & $\begin{array}{c}\text { Türkiye Tarımsal Araştırmalar Dergisi } \\
\text { dergipark.org.tr/tutad }\end{array}$ & $\begin{array}{l}\text { Turk J Agric Res } \\
\text { 2020, 7(1): 41-46 } \\
\text { @ TÜTAD } \\
\text { ISSN: 2148-2306 }\end{array}$ \\
\hline 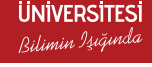 & Research Article & $\begin{array}{l}\text { e-ISSN: } 2528-858 X \\
\text { doi: } 10.19159 / \text { tutad.653918 }\end{array}$ \\
\hline
\end{tabular}

\title{
Effects of Moist-Cold Stratification and Gibberellic Acid Applications on Breaking Seed Dormancy in Foxtail Lily (Eremurus spectabilis M.Bieb.)*
}

\author{
Şeref AKDAĞ $\breve{G}^{1}$, Burcu TUNCER ${ }^{2 * *}$ \\ ${ }^{1}$ Van Yüzüncü Yll University, Institute of Natural and Applied Sciences, Department of Horticulture, Van, TURKEY \\ ${ }^{2}$ Van Yüzüncü Yıl University, Faculty of Agriculture, Department of Horticulture, Van, TURKEY
}

\begin{tabular}{ll}
\hline \multicolumn{1}{c}{ Received: 02.12 .2019} & Accepted: 14.02 .2020 \\
\hline ORCID ID (by author order) & \\
\hline (Dorcid.org/0000-0002-7889-584X (DiD orcid.org/0000-0002-4402-4536 \\
${ }^{*}$ Corresponding Author: brctuncer@gmail.com
\end{tabular}

\begin{abstract}
Eremurus spectabilis is a wild edible perennial herbaceous geophyte species with medicinal and popular ornamental uses. In this study, gibberellic acid $\left(\mathrm{GA}_{3}\right)$ with moist-cold stratification treatments were applied to break the dormancy of E. spectabilis seeds. For this purpose, seeds were soaked in gibberellic acid solutions $\left(\mathrm{GA}_{3}: 500\right.$ and $750 \mathrm{ppm}$ for 24 and 48 hours). Pretreated seeds were then subjected to moist-cold stratification treatments for different durations (30, 50,80 and 100 days) at $4{ }^{\circ} \mathrm{C}$. In 24-hour $\mathrm{GA}_{3}$ treatments, the germination and emergence ratios $(21.04 \%)$ were obtained from the $500 \mathrm{ppm} \mathrm{GA}_{3}$ dose and 100 days of stratification treatments. In 48 -hour $\mathrm{GA}_{3}$ treatments, the $\mathrm{GA}_{3}$ doses did not have any significant effect on germination and emergence ratios; the greatest germination ratios were obtained from the 500 ppm $(20.36 \%)$ and $750 \mathrm{ppm}(20.00 \%)$ doses and 100 days of stratification treatments, and the best emergence ratios were obtained from the $500 \mathrm{ppm} \mathrm{GA} 3$ dose and 100 days of stratification treatments $(18.51 \%)$. It is considered that it is beneficial to try the combinations of moist-cold applications with different treatments in future studies.
\end{abstract}

Keywords: Eremurus spectabilis, Liliaceae, seed, germination, emergence

\section{Introduction}

Eremurus spectabilis is a wild perennial herbaceous species and belongs to the Eremurus genus of the Liliaceae family (Tuzlac1, 1985). Plant shoots and leaves are consumed as a vegetable. Apart from nutritional values, the plants are also used for medicinal purposes. Different parts of the plant are used to treat fungal diseases, diabetes, jaundice and liver disorders in folk medicine (Baytop, 1984; Tuzlacı and Doğan, 2010; Pourfarzad et al., 2014). E. spectabilis has recently been categorized as a popular ornamental geophyte plant and used in cut-flower production practices, especially in mild climate zones (Schiappacasse et al., 2013).

In order to break the seed dormancy, hormone treatments, in particular gibberellic acid $\left(\mathrm{GA}_{3}\right)$ applications, have been applied to different species (Rahman et al., 2006; Sar1 et al., 2006; Rahnama-
Ghahfarokhi and Tavakkol-Afshari, 2007; Hassani et al., 2009). In addition, moist-cold stratification applications are very effective in breaking the physiological and morphophysiological dormancy of the seeds (Sar1 et al., 2006; Rouhi et al., 2010; Mancuso et al., 2012; Keskiner and Tuncer, 2019).

A review of the literature reveals that number of studies about the breaking of seed dormancy in E. sepectabilis is very limited (Güngör, 2002; Rahmanpour et al., 2005; Keskiner, 2017; Keskiner and Tuncer, 2019). In a previous study conducted with E. spectabilis, $0.0 \%-73.3 \%$ of germinations were achieved with moist-cold stratification treatments for different durations (Keskiner and Tuncer, 2019). In the study, 100 days of cold stratification treatments were found to be the most promising treatment, and very low germination rates were reported for single potassium nitrate $\left(\mathrm{KNO}_{3}\right)$, calcium chloride $\left(\mathrm{CaCl}_{2}\right)$ and $\mathrm{GA}_{3}$ treatments without moist-cold

\footnotetext{
": This study was a part of the M.Sc Thesis of first author's entitled "Different Combination Treaments to Improve Germination and Emergence Performance on Seeds of Eremurus spectabilis M.Bieb." accepted by the Institute of Natural and Applied Sciences of Van Yüzüncü Yı1l University.
} 
stratification treatments (Keskiner and Tuncer, 2019).

There is also a limited number of studies conducted on different species within the same genus. Mamut et al. (2014) reported the greatest germination ratio of $E$. anisopterus for seeds dry stored at a low temperature $\left(5 / 2{ }^{\circ} \mathrm{C}\right)$ for $12-18$ weeks followed by immersion in various $\mathrm{GA}_{3}(0.1$, 1 and $10 \mathrm{mmol} \mathrm{L}^{-1}$ ) solutions. In another study conducted with $E$. olgae, the greatest germination ratio (80\%) and germination speed (1.6 days) were reported for tip-cut and testa-abraded seeds immersed in a $0.08 \mathrm{M} \mathrm{GA}_{3}$ solution for 45 minutes (Rahmanpour et al., 2007).

The aim of this study was to examine the effect of moist-cold stratification $\left(4{ }^{\circ} \mathrm{C}\right)$ and $\mathrm{GA}_{3}$ treatments on breaking seed dormancy and enhancing germination and emergence of E. spectabilis.

\section{Materials and Methods}

The mature seeds of E. spectabilis were collected from Gürpinar town (38 $8^{\circ} 8^{\prime} 20.75^{\prime \prime} \mathrm{N}, 4^{\circ} 30^{\prime}$ $\left.55.15^{\prime \prime} \mathrm{E}\right)$ in Van province of Turkey. This study was conducted at Van Yüzüncü Y1l University Faculty of Agriculture from 2017 to 2018. The seeds were kept in a $0.3 \%$ Benomyl (Fungicide) solution for an hour, washed with distilled water and kept in distilled water for 1 hour (Lee et al., 2015; Keskiner and Tuncer, 2019). For surface sterilization, $30 \%$ sodium hypochlorite solution $(\mathrm{NaOCl})$ was applied to seeds for 10 minutes and rinsed three times with double distilled water for 5 minutes. Seed sowing and moistening practices were performed in a laminar flow cabinet and double distilled water was used in the irrigations.

For $\mathrm{GA}_{3}$ treatments, the sterilized seeds were separated into groups for treatments and immersed in $500 \mathrm{ppm}$ and $750 \mathrm{ppm} \mathrm{GA}_{3}$ solutions for 24 and 48 hours. Then, the seeds were shaken and washed with double distilled water. Seeds were placed on drying papers to remove any excess water and seeded in Petri dishes placed in a laminar flow cabinet. The Petri dishes were closed and placed in polyethylene bags. For moist-cold stratification treatments, seeds in Petri dishes were treated at 4 ${ }^{\circ} \mathrm{C}$ for 30, 50, 80 and 100 days (Güngör, 2002; Keskiner and Tuncer, 2019). Then the seeds were germinated in an incubator at a temperature of 12$13{ }^{\circ} \mathrm{C}$ under dark conditions until optimum germination was achieved (Keskiner and Tuncer, 2019).

At the end of the tests, the germination ratio (GR), emergence ratio (ER), germination speed (GS), emergence speed (ES), mean germination time (MGT), mean emergence time (MET), vigor index (VI), radicle length (RL), plumule length (PL) and seedling length (SL) (cm) were calculated. The following equations were used in the calculations (Abdul-Baki and Anderson, 1973; Murillo-Amador et al., 2002; Y1ldırım and Güvenç, 2006; Keskiner and Tuncer, 2019):

$$
(\mathrm{GR})(\mathrm{ER})(\%)=(\mathrm{G} / \mathrm{T}) \times 100
$$

$(\mathrm{MGT})(\mathrm{MET})($ day $)=[($ 1.day G x 1. day $)+$ (2. day G x 2.day) $+\ldots+$ (n.day G x n.day)] / Total G

Germination or emergence speed $=\mathrm{n} 1 / \mathrm{t} 1+\mathrm{n} 2 /$ $\mathrm{t} 2+\ldots \ldots \ldots+\mathrm{nn} / \mathrm{tn}$

Vigor index $=$ Ls $x$ GR $/ 100$

In the equations; $n 1$ and $n 2$ denote number of germinated or emerged seeds, $t 1$ and $t 2$ denote number of days for germination or emergence, Ls means mean radicle + plumule length, $G$ states number of germinated or emerged seeds, $T$ denotes total number of seeds.

This experiment was established according to completely randomized design with 3 replications (25 seeds per replicate). Data for germination and emergence parameters were subjected to arcsine transformation before statistical analysis. The analysis was performed using Statgraphics statistical software (Statgraphics Centurion XVII Version 17.1.03) and means were separated by Duncan's multiple range test.

\section{Results and Discussion}

The effects of immersion in different doses of $\mathrm{GA}_{3}$ solutions for 24 hours and moist-cold stratification treatments on germination and emergence rates are given in Tables 1 and 2 .

The effects of different stratification durations on GR and MGT were found to be significant ( $\mathrm{p}<$ $0.01)$. The greatest GR (21.04\%) was obtained from 500 ppm $\mathrm{GA}_{3}$ application with 100 days of stratification. It was followed by $500 \mathrm{ppm} \mathrm{\textrm {GA } _ { 3 }}$ with 80 days of stratification $(17.53 \%)$ and 750 ppm $\mathrm{GA}_{3}$ with 100 days of stratification (14.58\%), respectively. The average of the $\mathrm{GA}_{3}$ doses had significant effects only on MGT. MGT varied between 0.00 and 41.41 days depending on the dose. In the emergence experiments, the effects of different stratification durations $(p<0.01)$, doses $(\mathrm{p}<0.01$ at ER, RL and SL, $<<0.05$ at other emergence parameters) and interactions $(p<0.01)$ on all parameters were found to be significant.

The greatest ER was obtained from $500 \mathrm{ppm}$ with 100 days of stratification treatments $(21.04 \%)$ and 50 days of stratification treatments $(17.53 \%)$ 
Table 1. Effects of different $\mathrm{GA}_{3}$ doses (24 hours) and moist-cold stratification treatments (MCST) on germination rate (GR), germination speed (GS) and mean germination time (MGT)

\begin{tabular}{|c|c|c|c|c|}
\hline $\mathrm{GA}_{3}$ doses & $\begin{array}{c}\text { MCST } \\
\text { (day) }\end{array}$ & $\begin{array}{l}\text { GR } \\
(\%)\end{array}$ & $\begin{array}{c}\text { GS } \\
\text { (day) }\end{array}$ & $\begin{array}{l}\text { MGT } \\
\text { (day) }\end{array}$ \\
\hline \multirow{4}{*}{500 ppm } & 30 & $0.00 \mathrm{e}$ & $0.00 \mathrm{~b}$ & $0.00 \mathrm{f}$ \\
\hline & 50 & $0.00 \mathrm{e}$ & $0.00 \mathrm{~b}$ & $0.00 \mathrm{f}$ \\
\hline & 80 & $17.53 \mathrm{~b}$ & $0.24 \mathrm{ab}$ & $18.66 \mathrm{~d}$ \\
\hline & 100 & $21.04 \mathrm{a}$ & $0.46 \mathrm{a}$ & $37.98 \mathrm{~b}$ \\
\hline Average & & 9.64 & 0.17 & $14.16^{2}$ \\
\hline \multirow{4}{*}{$750 \mathrm{ppm}$} & 30 & $4.16 \mathrm{~d}$ & $0.04 \mathrm{~b}$ & $4.66 \mathrm{e}$ \\
\hline & 50 & $2.08 \mathrm{de}$ & $0.02 \mathrm{~b}$ & $4.66 \mathrm{e}$ \\
\hline & 80 & $12.41 \mathrm{c}$ & $0.08 \mathrm{~b}$ & $22.08 \mathrm{c}$ \\
\hline & 100 & $14.58 \mathrm{bc}$ & $0.05 \mathrm{~b}$ & $41.41 \mathrm{a}$ \\
\hline Average & & 8.31 & 0.05 & $18.20^{1}$ \\
\hline \multirow{4}{*}{$\begin{array}{l}\text { Avarage of } \\
\text { MCST }\end{array}$} & 30 & $2.08 \mathrm{C}$ & $0.02 \mathrm{~B}$ & $2.33 \mathrm{C}$ \\
\hline & 50 & $1.04 \mathrm{C}$ & $0.01 \mathrm{~B}$ & $2.33 \mathrm{C}$ \\
\hline & 80 & $14.97 \mathrm{~B}$ & $0.16 \mathrm{AB}$ & $20.37 \mathrm{~B}$ \\
\hline & 100 & $17.81 \mathrm{~A}$ & $0.25 \mathrm{~A}$ & $39.70 \mathrm{~A}$ \\
\hline \multicolumn{5}{|c|}{ P Value } \\
\hline $\mathrm{GA}_{3}$ & & ns & ns & $0.001^{* *}$ \\
\hline MCST & & $0.0001^{* *}$ & $\mathrm{~ns}$ & $0.0001^{* *}$ \\
\hline $\mathrm{GA}_{3} \times \mathrm{MCST}$ & & $0.0001^{* *}$ & ns & $0.0001^{* *}$ \\
\hline
\end{tabular}

Different capital letters in the same column indicate differences among the moist-cold stratification time, different numbers ${ }^{(1,2)}$ indicate differences among $\mathrm{GA}_{3}$ doses and different small letters indicate significant differences between interactions, ${ }^{* *}$ : Significant at $\mathrm{p}<0.01$ level, ns: Not significant

(Table 2). For the ER and the MET, 500 ppm dose was more successful than other treatments. MET varied between 0.00 and 51.33 days, RL varied between 0.00 and $0.60 \mathrm{~cm}$, PL varied between 0.00 and $5.66 \mathrm{~cm}$, SL varied between 0.00 and $6.10 \mathrm{~cm}$, and VI values varied between 0.00 and 137.33 Increases were observed in RL, PL, and SL at an average of $750 \mathrm{ppm}$ and increases were observed in VI at 500 ppm dose average (Table 2).

The effects of 48-hour immersion in $\mathrm{GA}_{3}$ solutions are given in Table 3 . The average of the stratification durations was found to be significant for all germination parameters, and the average of the doses was found to be significant only on GS $(\mathrm{p}<0.01)$. The greatest GR was observed in 500 ppm $(20.36 \%)$ and 750 ppm $\mathrm{GA}_{3}(20.00 \%)$ with 100 days of stratification treatments. The MGT varied between 0.66 and 55.58 days (Table 3 ).

The emergence parameters are summarized in Table 4. While stratification durations were found to be significant for all parameters except RL, average of the doses was found to be significant for PL, SL and VI. ER varied between $1.85 \%$ and $18.51 \%$. ER was more successful in $500 \mathrm{ppm}$ with 100 days of stratification treatments $(18.51 \%), 750$ ppm with 100 days of stratification treatments $(15.00 \%)$ and 80 days of stratification treatments (13.33\%) (Table 4).

Güngör (2002) was unable to get any E. spectabilis seeds to germinate with different $\mathrm{GA}_{3}$ doses (250, 500, 750 and $1000 \mathrm{ppm}$ ). Keskiner and Tuncer (2019) were not able to get any positive outcomes from single $\mathrm{GA}_{3}$ treatments (without moist-cold stratification treatments) and reported the greatest germination $(1.66 \%)$ for a 750 ppm $\mathrm{GA}_{3}$ dose.

Table 2. Effects of different $\mathrm{GA}_{3}$ doses (24 hours) and moist-cold stratification treatments (MCST) on emergence rate (ER), emergence speed (ES), mean emergence time (MET), radicle length (RL), plumule length $(\mathrm{PL})$, seedling length (SL) and vigor index (VI)

\begin{tabular}{|c|c|c|c|c|c|c|c|c|}
\hline $\mathrm{GA}_{3}$ doses & $\begin{array}{c}\text { MCST } \\
\text { (day) }\end{array}$ & $\begin{array}{l}\text { ER } \\
(\%) \\
\end{array}$ & $\begin{array}{c}\text { ES } \\
\text { (day) }\end{array}$ & $\begin{array}{l}\text { MET } \\
\text { (day) }\end{array}$ & $\begin{array}{l}\mathrm{RL} \\
(\mathrm{cm})\end{array}$ & $\begin{array}{l}\mathrm{PL} \\
(\mathrm{cm})\end{array}$ & $\begin{array}{c}\mathrm{SL} \\
(\mathrm{cm})\end{array}$ & VI \\
\hline \multirow{4}{*}{500 ppm } & 30 & $0.00 \mathrm{e}$ & $0.00 \mathrm{~b}$ & $0.00 \mathrm{e}$ & $0.00 \mathrm{c}$ & $0.00 \mathrm{~d}$ & $0.00 \mathrm{~d}$ & $0.00 \mathrm{f}$ \\
\hline & 50 & $0.00 \mathrm{e}$ & $0.00 \mathrm{~b}$ & $0.00 \mathrm{e}$ & $0.00 \mathrm{c}$ & $0.00 \mathrm{~d}$ & $0.00 \mathrm{~d}$ & $0.00 \mathrm{f}$ \\
\hline & 80 & $17.53 \mathrm{~b}$ & $0.96 \mathrm{a}$ & $11.25 \mathrm{c}$ & $0.60 \mathrm{a}$ & $5.00 \mathrm{a}$ & $5.60 \mathrm{a}$ & $94.36 \mathrm{~b}$ \\
\hline & 100 & $21.04 \mathrm{a}$ & $1.09 \mathrm{a}$ & $22.11 \mathrm{~b}$ & $0.43 \mathrm{a}$ & $5.66 \mathrm{a}$ & $6.10 \mathrm{a}$ & $137.33 \mathrm{a}$ \\
\hline Average & & $9.64^{1}$ & $0.51^{1}$ & $8.34^{2}$ & $0.25^{2}$ & $2.66^{2}$ & $2.92^{2}$ & $57.92^{1}$ \\
\hline \multirow{4}{*}{750 ppm } & 30 & $4.16 \mathrm{~d}$ & $0.08 \mathrm{~b}$ & $2.66 \mathrm{~d}$ & $0.43 \mathrm{a}$ & $3.33 \mathrm{bc}$ & $3.76 b c$ & $23.54 \mathrm{e}$ \\
\hline & 50 & $2.08 \mathrm{de}$ & $0.04 \mathrm{~b}$ & $2.33 \mathrm{de}$ & $0.20 \mathrm{bc}$ & $3.50 \mathrm{bc}$ & $3.70 \mathrm{c}$ & $23.12 \mathrm{e}$ \\
\hline & 80 & $12.50 \mathrm{c}$ & $0.05 \mathrm{~b}$ & $23.33 \mathrm{~b}$ & $0.40 \mathrm{ab}$ & $2.16 \mathrm{c}$ & $2.56 \mathrm{c}$ & $45.00 \mathrm{~d}$ \\
\hline & 100 & $14.58 \mathrm{c}$ & $0.04 \mathrm{~b}$ & $51.33 \mathrm{a}$ & $0.53 \mathrm{a}$ & $4.66 \mathrm{ab}$ & $5.20 \mathrm{ab}$ & $74.16 \mathrm{c}$ \\
\hline Average & & $8.33^{2}$ & $0.05^{2}$ & $19.91^{1}$ & $0.39^{1}$ & $3.41^{1}$ & $3.80^{1}$ & $41.45^{2}$ \\
\hline \multirow{4}{*}{$\begin{array}{l}\text { Average of } \\
\text { MCST }\end{array}$} & 30 & $2.08 \mathrm{C}$ & $0.04 \mathrm{~B}$ & $1.33 \mathrm{C}$ & $0.21 \mathrm{~B}$ & $1.66 \mathrm{C}$ & $1.88 \mathrm{C}$ & $11.17 \mathrm{C}$ \\
\hline & 50 & $1.04 \mathrm{C}$ & $0.02 \mathrm{~B}$ & $1.16 \mathrm{C}$ & $0.10 \mathrm{~B}$ & $1.75 \mathrm{C}$ & $1.85 \mathrm{C}$ & $11.56 \mathrm{C}$ \\
\hline & 80 & $15.01 \mathrm{~B}$ & $0.51 \mathrm{~A}$ & $17.29 \mathrm{~B}$ & $0.50 \mathrm{~A}$ & $3.58 \mathrm{~B}$ & $4.08 \mathrm{~B}$ & $69.68 \mathrm{~B}$ \\
\hline & 100 & $17.81 \mathrm{~A}$ & $0.56 \mathrm{~A}$ & $36.72 \mathrm{~A}$ & $0.48 \mathrm{~A}$ & $5.16 \mathrm{~A}$ & $5.65 \mathrm{~A}$ & $105.75 \mathrm{~A}$ \\
\hline \multicolumn{9}{|c|}{ P Value } \\
\hline $\mathrm{GA}_{3}$ & & $0.020^{*}$ & $0.001^{* *}$ & $0.000^{* *}$ & $0.031^{*}$ & $0.004^{* *}$ & $0.031^{*}$ & $0.000^{* *}$ \\
\hline MCST & & $0.000^{* *}$ & $0.006^{* *}$ & $0.000^{* *}$ & $0.003^{* *}$ & $0.006^{* *}$ & $0.004^{* *}$ & $0.000^{* *}$ \\
\hline $\mathrm{GA}_{3} \times \mathrm{MCST}$ & & $0.000^{* *}$ & $0.004^{* *}$ & $0.000^{* *}$ & $0.010^{* *}$ & $0.000^{* *}$ & $0.000^{* *}$ & $0.000^{* *}$ \\
\hline
\end{tabular}


Table 3. Effects of different $\mathrm{GA}_{3}$ doses (48 hours) and moist-cold stratification treatments (MCST) on germination rate (GR), germination speed (GS) and mean germination time (MGT)

\begin{tabular}{|c|c|c|c|c|}
\hline $\begin{array}{l}\mathrm{GA}_{3} \\
\text { doses }\end{array}$ & $\begin{array}{c}\text { MCST } \\
\text { (day) }\end{array}$ & $\begin{array}{l}\text { GR } \\
(\%)\end{array}$ & $\begin{array}{c}\text { GS } \\
\text { (day) }\end{array}$ & $\begin{array}{l}\text { MGT } \\
\text { (day) }\end{array}$ \\
\hline \multirow{4}{*}{500 ppm } & 30 & $1.85 \mathrm{~d}$ & $0.04 \mathrm{~b}$ & $2.33 \mathrm{f}$ \\
\hline & 50 & $5.55 \mathrm{~cd}$ & $0.09 \mathrm{~b}$ & $7.16 \mathrm{e}$ \\
\hline & 80 & $7.40 \mathrm{c}$ & $0.03 \mathrm{~b}$ & $40.83 \mathrm{~b}$ \\
\hline & 100 & $20.36 \mathrm{a}$ & $0.06 \mathrm{~b}$ & $57.24 \mathrm{a}$ \\
\hline Average & & 8.79 & $0.06^{2}$ & 26.89 \\
\hline \multirow{4}{*}{750 ppm } & 30 & $3.33 \mathrm{~d}$ & $0.66 \mathrm{a}$ & $0.66 \mathrm{f}$ \\
\hline & 50 & $5.00 \mathrm{~cd}$ & $0.04 \mathrm{~b}$ & $18.66 \mathrm{~d}$ \\
\hline & 80 & $13.33 \mathrm{~b}$ & $0.07 \mathrm{~b}$ & $26.44 \mathrm{c}$ \\
\hline & 100 & $20.00 \mathrm{a}$ & $0.11 \mathrm{~b}$ & $55.58 \mathrm{a}$ \\
\hline \multirow[t]{2}{*}{ Average } & & 10.41 & $0.22^{1}$ & 25.33 \\
\hline & 30 & $2.59 \mathrm{C}$ & $0.35 \mathrm{~A}$ & $1.50 \mathrm{D}$ \\
\hline Avarage & 50 & $5.27 \mathrm{C}$ & $0.06 \mathrm{~B}$ & $12.91 \mathrm{C}$ \\
\hline \multirow[t]{2}{*}{ of MCST } & 80 & $10.36 \mathrm{~B}$ & $0.05 \mathrm{~B}$ & $33.63 \mathrm{~B}$ \\
\hline & 100 & $20.18 \mathrm{~A}$ & $0.08 \mathrm{~B}$ & $56.41 \mathrm{~A}$ \\
\hline \multicolumn{5}{|c|}{ P Value } \\
\hline \multicolumn{2}{|l|}{$\mathrm{GA}_{3}$} & $\mathrm{~ns}$ & $0.003^{* *}$ & $\mathrm{~ns}$ \\
\hline \multicolumn{2}{|l|}{ MCST } & $0.000^{* *}$ & $0.008^{* *}$ & $0.000^{* *}$ \\
\hline \multicolumn{2}{|c|}{$\mathrm{GA}_{3} \times \mathrm{MCST}$} & $\mathrm{ns}$ & $0.004^{* *}$ & $0.000^{* *}$ \\
\hline
\end{tabular}

Different capital letters in the same column indicate differences among the moist-cold stratification time, different numbers ${ }^{(1,2)}$ indicate differences among $\mathrm{GA}_{3}$ doses and different small letters indicate significant differences between interactions, $* *$ : Significant at $\mathrm{p}<0.01$ level, ns: Not significant

Present findings for 24-hour $\mathrm{GA}_{3}$ treatments were greater at $500 \mathrm{ppm}$ average values for GR and ER (9.64\%), MGT (14.16 days), MET (8.34 days) and VI (57.92) values. On the other hand,
RL $(0.39 \mathrm{~cm})$, PL $(3.41 \mathrm{~cm})$ and SL $(3.80 \mathrm{~cm})$ values were greater at the dose of $750 \mathrm{ppm}$. For 48-hour $\mathrm{GA}_{3}$ treatments, an average of $750 \mathrm{ppm}$ was more successful for the GR $(10.41 \%)$, ER (8.33\%), MGT (25.33 days) and MET (25.40 days) whereas $500 \mathrm{ppm}$ was more remarkable for RL $(0.42 \mathrm{~cm})$, PL $(5.25 \mathrm{~cm}), \mathrm{SL}(5.67 \mathrm{~cm})$ and VI (65.32) parameters. Keskiner and Tuncer (2019) reported that they applied only moist-cold stratification without any other application to E. spectabilis seeds for 30-100 days and maximum germination $(73.30 \%)$ was obtained from the 100 days moist cold application. Present germination and emergence values were lower than the values reported by Keskiner and Tuncer (2019). At low germination and low emergence values, $\mathrm{GA}_{3}$ and moist-cold stratification applications are thought to have an antagonistic effect on each other. Rouhi et al. (2010) applied moist-cold stratification to Tulipa kaufmanniana Regel (Liliaceae) seeds for 7 weeks and indicated $500 \mathrm{ppm} \mathrm{GA}_{3}$ dose as a promising treatment for germination parameters.

Apart from moist-cold stratification treatments, $\mathrm{GA}_{3}$ treatments were combined with different treatments in previous studies. Rahmanpour et al. (2005) reported a GR of 53\% for mechanically abraded E. spectabilis seeds immersed in a $0.01 \mathrm{M}$ $\mathrm{GA}_{3}$ solution for 45 minutes. Rahmanpour et al. (2005), for E. spectabilis, and Rahmanpour et al. (2007), for E. olgae, reported that the mechanical abrasion of seeds with some chemicals and tip-

Table 4. Effects of different $\mathrm{GA}_{3}$ doses (48 hours) and moist-cold stratification treatments (MCST) on emergence rate (ER), emergence speed (ES), mean emergence time (MET), radicle (RL), plumula (PL) and seedling length (SL) and vigor index (VI)

\begin{tabular}{|c|c|c|c|c|c|c|c|c|}
\hline $\mathrm{GA}_{3}$ doses & $\begin{array}{c}\text { MCST } \\
\text { (day) }\end{array}$ & $\begin{array}{l}\text { ER } \\
(\%)\end{array}$ & $\begin{array}{c}\text { ES } \\
\text { (day) }\end{array}$ & $\begin{array}{l}\text { MET } \\
\text { (day) }\end{array}$ & $\begin{array}{l}\mathrm{RL} \\
(\mathrm{cm})\end{array}$ & $\begin{array}{c}\mathrm{PL} \\
(\mathrm{cm})\end{array}$ & $\begin{array}{l}\mathrm{SL} \\
(\mathrm{cm})\end{array}$ & VI \\
\hline \multirow{4}{*}{500 ppm } & 30 & $1.85 \mathrm{e}$ & $0.33 \mathrm{a}-\mathrm{c}$ & $0.33 \mathrm{~g}$ & $0.16 \mathrm{~d}$ & $2.83 \mathrm{de}$ & $3.00 \mathrm{de}$ & $16.65 \mathrm{f}$ \\
\hline & 50 & $5.55 \mathrm{~cd}$ & $0.40 \mathrm{ab}$ & $4.83 \mathrm{f}$ & $0.40 \mathrm{a}-\mathrm{c}$ & $4.66 \mathrm{bc}$ & $5.06 \mathrm{bc}$ & $37.57 \mathrm{~d}$ \\
\hline & 80 & $7.40 \mathrm{c}$ & $0.03 \mathrm{c}$ & $37.33 \mathrm{c}$ & $0.53 \mathrm{ab}$ & $6.83 \mathrm{a}$ & $7.36 \mathrm{a}$ & $55.71 \mathrm{c}$ \\
\hline & 100 & $18.51 \mathrm{a}$ & $0.05 \mathrm{bc}$ & $55.37 \mathrm{~b}$ & $0.60 \mathrm{a}$ & $6.66 \mathrm{a}$ & $7.26 \mathrm{a}$ & $151.36 \mathrm{a}$ \\
\hline Average & & 8.33 & 0.20 & 24.46 & 0.42 & $5.25^{1}$ & $5.67^{1}$ & $65.32^{1}$ \\
\hline \multirow{4}{*}{750 ppm } & 30 & $3.33 \mathrm{de}$ & $0.66 \mathrm{a}$ & $0.66 \mathrm{~g}$ & $0.33 \mathrm{~b}-\mathrm{d}$ & $4.30 \mathrm{~b}-\mathrm{d}$ & $4.66 \mathrm{~b}-\mathrm{d}$ & $23.33 \mathrm{ef}$ \\
\hline & 50 & $3.66 \mathrm{de}$ & $0.05 \mathrm{bc}$ & $9.33 \mathrm{e}$ & $0.26 \mathrm{~cd}$ & $3.30 \mathrm{c}-\mathrm{e}$ & $3.60 \mathrm{c}-\mathrm{e}$ & $24.66 \mathrm{e}$ \\
\hline & 80 & $13.33 \mathrm{~b}$ & $0.06 \mathrm{bc}$ & $24.11 \mathrm{~d}$ & $0.40 \mathrm{a}-\mathrm{c}$ & $2.33 \mathrm{e}$ & $2.73 \mathrm{e}$ & $56.66 \mathrm{c}$ \\
\hline & 100 & $15.00 \mathrm{~b}$ & $0.05 \mathrm{bc}$ & $67.51 \mathrm{a}$ & $0.40 \mathrm{a}-\mathrm{c}$ & $5.16 \mathrm{ab}$ & $5.56 \mathrm{ab}$ & $126.83 \mathrm{~b}$ \\
\hline Average & & 8.83 & 0.20 & 25.40 & 0.35 & $3.79^{2}$ & $4.14^{2}$ & $57.87^{2}$ \\
\hline \multirow{4}{*}{$\begin{array}{l}\text { Avarage of } \\
\text { MCST }\end{array}$} & 30 & $2.59 \mathrm{D}$ & $0.50 \mathrm{~A}$ & $0.50 \mathrm{D}$ & $0.25 \mathrm{C}$ & $3.58 \mathrm{~B}$ & $3.83 \mathrm{~B}$ & $19.99 \mathrm{D}$ \\
\hline & 50 & $4.61 \mathrm{C}$ & $0.22 \mathrm{~B}$ & $7.08 \mathrm{C}$ & $0.33 \mathrm{BC}$ & $4.00 \mathrm{~B}$ & $4.33 \mathrm{~B}$ & $31.12 \mathrm{C}$ \\
\hline & 80 & $10.3 \mathrm{~B}$ & $0.05 \mathrm{~B}$ & $30.72 \mathrm{~B}$ & $0.46 \mathrm{AB}$ & $4.58 \mathrm{~B}$ & $5.05 \mathrm{AB}$ & $56.19 \mathrm{~B}$ \\
\hline & 100 & $16.7 \mathrm{~A}$ & $0.05 \mathrm{~B}$ & $61.44 \mathrm{~A}$ & $0.50 \mathrm{~A}$ & $5.91 \mathrm{~A}$ & $6.41 \mathrm{~A}$ & $139.10 \mathrm{~A}$ \\
\hline \multicolumn{9}{|c|}{ P Value } \\
\hline $\mathrm{GA}_{3}$ & & $\mathrm{~ns}$ & $\mathrm{~ns}$ & ns & $\mathrm{ns}$ & $0.044^{*}$ & $0.005^{* *}$ & $0.001^{* *}$ \\
\hline MCST & & $0.000^{* *}$ & $0.003^{* *}$ & $0.000^{* *}$ & $0.019^{*}$ & $0.009^{* *}$ & $0.008^{* *}$ & $0.000^{* *}$ \\
\hline $\mathrm{GA}_{3} \times \mathrm{MCST}$ & & $0.000^{* *}$ & ns & $0.000^{* *}$ & ns & $0.003^{* *}$ & $0.002^{* *}$ & $0.001^{* *}$ \\
\hline
\end{tabular}


cutting treatments had positive impacts on germination and emergence parameters. At the end of 3 weeks, Rahmanpour et al. (2005) reported the greatest germination rate $(53.3 \%)$ and germination speed ( 0.88 days) for tip-cut seeds of $E$. spectabilis subjected to a pretreatment of immersion in a $35 \%$ sodium hypochlorite solution for 24 and 48 hours and $0.01 \mathrm{M} \mathrm{GA}_{3}$ and citric acid $\left(50 \mathrm{mg} \mathrm{L}^{-1}\right)$ solutions for 45 minutes.

In another study, Rahmanpour et al. (2007) reported a $70 \%$ germination rate for citric acidtreated tip-cut seeds of E. olgae and $80 \%$ germination ratio for different combined treatments (immersion in water for 24-48 hours plus tip-cutting plus immersion in a $0.08 \mathrm{M} \mathrm{GA}_{3}$ solution for 45 minutes). Such findings do not comply with the present ones because of the different species used.

\section{Conclusions}

This study was the first report to investigate the effect of combined $\mathrm{GA}_{3}$ applications with moistcold stratification on E. spectabilis in order to break seed dormancy. In conclusion, it was determined that the combination of $\mathrm{GA}_{3}$ and moist-cold stratification applications together had an antagonistic effect in breaking the dormancy of E. spectabilis seeds. For this reason, it is considered that it is beneficial to evaluate various combinations of moist-cold applications with different treatments (especially seed tip cutting) in future studies.

\section{Acknowledgments}

Authors would like to thank Van Yüzüncü Y1l University, Scientific Research Projects Department for the financial support (Project No: FYL-2017-6581).

\section{References}

Abdul Baki, A.A., Anderson, J.D., 1973. Vigor determination in soybean by multiple criteria. Crop Science, 13(6): 630-633.

Baytop, T., 1984. Therapy with Medicinal Plants. Istanbul University Publishing, Istanbul, Turkey.

Güngör, F., 2002. Investigations on the morphological, biological characteristics and cultivation possibilities of Eremurus spectabilis Bieb Fedtsch., Prangos ferulacea Lindl and Hippomarathum microcarpum Bieb as growing wildly. Ph.D. thesis, Ataturk University Graduated School of Natural and Applied Sciences, Erzurum. (in Turkish).

Hassani, S.B., Saboora, A., Radjabian, T., Fallah Husseini, H., 2009. Effects of temperature, GA3 and cytokinıns on breaking seed dormancy of Ferula assa-foetuda L. Iranian Journal of Science \& Technology, Transaction A, 33(A1): 75-85.

Keskiner, K., 2017. Investigations on applications of breaking seed dormancy in grown wild Eremurus spectabilis M.Bieb. M.Sc. thesis, Van Yüzüncü Yıl University Graduated School of Natural and Applied Sciences, Van. (in Turkish).

Keskiner, K., Tuncer, B., 2019. Dormancy breaking treatments for wild Eremurus spectabilis M.Bieb. seeds. Fresenius Environmental Bulletin, 28(2A): 1167-1173.

Lee, S.Y., Rhie, Y.H., Kim, K.S., 2015. Non-deep simple morphophysiological dormancy in seeds of Thalictrum rochebrunianum, an endemic perennial herb in the Korean Peninsula. Horticulture Environment and Biotechnology, 56(3): 366-375.

Mamut, J., Tan, D.Y., Baskin, C.C., Baskin, J.M., 2014. Intermediate complex morphophysiological dormancy in seeds of the cold desert sand dune geophyte Eremurus anisopterus (Xanthorrhoeaceae; Liliaceae s.1.). Annals of Botany, 114(5): 991-999.

Mancuso, E., Bedini, G., Peruzzi, L., 2012. Morphology, germination, and storage behaviour in seeds of Tuscan populations of Fritillaria montana (Liliaceae), a rare perennial geophyte in Italy. Turkish Journal of Botany, 36(2): 161-166.

Murillo-Amador, B., López-Aguilar, R., Kaya, C., Larrinaga Mayoral, J., Flores-Hernández, A., 2002. Comparative effects of $\mathrm{NaCl}$ and polyethylene glycol on germination, emergence and seedling growth of cowpea. Journal of Agronomy and Crop Science, 188(4): 235-247.

Pourfarzad, A., Najafi, M.B.H., Khodaparast, M.H.H., Khayyat, M.H., Malekpour, A., 2014. Fractionation of (Eremurus spectabilis) fructans by ethanol: BoxBehnken design and principal component analysis. Carbohydrate Polymers, 106: 374-383.

Rahman, M.H., Haque, M.S., Karim, M.A., Ahmed, M., 2006. Effects of gibberellic acid $\left(\mathrm{GA}_{3}\right)$ on breaking dormancy in garlic (Allium sativum L.). International Journal of Agriculture \& Biology, 8(1): 63-65.

Rahmanpour, A., Majd, A., Chalabian, F., 2005. Effects of gibberellic and citric acid on germination percentage, speed of germination and seed vigor of (Eremurus spectabilis M.B). Iranian Journal of Rangelands and Forests Plant Breeding and Genetic Research, 13(1/19): 53-65.

Rahmanpour, A., Majd, A., Chalabian, F., 2007. The effect of hormones and mechanical treatments on seed germination of Eremurus olgae Regel. Iranian Journal of Medicinal and Aromatic Plants, 23(1/35): 111-120.

Rahnama-Ghahfarokhi, A., Tavakkol-Afshari, R., 2007. Methods for dormancy breaking and germination of Galbanum seeds (Ferula gummosa). Asian Journal of Plant Science, 6(4): 611-616.

Rouhi, H.R., Shakarami, K., Afshari, R.T., 2010. Seed treatments to overcome dormancy of waterlily tulip (Tulipa kaufmanniana Regel.). Australian Journal of Crop Science, 4(9): 718-721. 
Sarı, A.O., Oğuz, B., Bilgiç, A., 2006. Breaking seed dormancy of laurel (Laurus nobilis L.). New Forests, 31(3): 403-408.

Schiappacasse, F., Szigeti, J.C., Manzano, E., Kamenetsky, R., 2013. Eremurus as a new cut flower crop in Aysen, chile: Introduction from the northern hemisphere. Acta Horticulturae, 1002: 115121.
Tuzlacı, E., 1985. Türkiye'nin çiriş otları I. Marmara Üniversitesi Eczacılık Dergisi, 1(1-2): 69-89.

Tuzlacı, E., Doğan, A., 2010. Turkish folk medicinal plants, IX: Ovacik (Tunceli). Marmara Pharmaceutical Journal, 14(3): 136-143.

Yıldırım, E., Güvenç, I., 2006. Salt tolerance of pepper cultivars during germination and seedling growth. Turkish Journal of Agriculture and Forestry, 30(5): 347-353. 